\title{
老人保健事業による基本健康診査受診と国保医療費との関連
}

\author{
竹 内 清 美 \\ 愛知医科大学医学部衛生学講座
}

\section{The Relationship between Undergoing a Basic Health Checkup Based on the Health and Medical Services Law for the Aged and Medical Expenditure Covered under the National Health Insurance in Japan}

\author{
Kiyomi TAKEUCHI
}

Department of Health and Psychosocial Medicine, Aichi Medical University School of Medicine, Aichi

\begin{abstract}
Objectives: This study examined the relationship between undergoing the basic health checkup based on the Health and Medical Services Law for the Aged among urban residents and medical expenditure covered under the National Health Insurance in Japan.

Methods: The subjects were all residents of a city with a population of three hundred and fifty thousand, covered by National Health Insurance and over forty years of age. Medical expenditure was compared by age and sex between examinees who had undergone the basic health checkup for the past three years running and non-examinees who had had no checkup.

In addition, from the results of a questionnaire survey of randomly sampled citizens, we compared the living habits of the above two groups, the examinees and non-examinees.

Results: For outpatients, the medical expenditure per case, the medical expenditure per capita for seniors, and the medical expenditure per day were lower, and the number of examination days per case and the examination rate (the number of receipts per capita) were higher in the examinee group than in the nonexaminee group. For inpatients, the medical expenditure per case, the medical expenditure per capita, the medical expenditure per day for seniors, the number of examination days per case, and the examination rate were lower in the examinee group compared to the non-examinee group. The increase in medical expenditure with age was less in the examinee group than in the non-examinee group. In men, the examinees had significantly better living habits (especially exercise and meals) than the non-examinees. No differences in living habits were found in women.

Conclusions: Medical expenditure was lower among examinees than non-examinees. In men, regular examinees had better living habits than non-examinees.
\end{abstract}

Key words: medical expenditure（医療費）, basic health checkup（基本健康診查）, the National Health Insurance（国民健康保険）， living habits（生活習慣）, undergoing health checkups（健診受診）

\section{緒言}

我が国では 1961 年に国民皆保険制度が導入され, 経済 の発展とともに, 国民の健康状態も改善し, 現在では世 界第一の長寿国となった ${ }^{1)}$ 。その一方で，近年の急激な

受付 2001 年 8 月 28 日, 受理 2001 年 11 月 12 日

Reprint requests to: Kiyomi TAKEUCHI

Department of Health and Psychosocial Medicine, Aichi Medical University School of Medicine, Aichi, 480-1195, Japan

TEL: +81(561)62-3311 内線 $(2371,2312)$, FAX: +81(561)63-8552
少子高齢化や医療の高度化により，年々医療費は高騰し 続けている ${ }^{1)}$ 。しかし，長引く不況と景気低迷で右肩上 がりの経済成長は見込めず，ますます保健・医療を取り 巻く財政は逼迫していくものと思われる。したがって今 後は, 限られた予算を効率的に運用するために，より費 用対効果の優れた保健事業を選択して展開していくこと が必要である。

一方, 1982 年に制定され, 1983 年に施行された老人保 健法に基づき, 市町村によって 40 歳以上の住民に基本健 康診査が実施されてきた。老人保健法は, 疾病の予防, 
日衛誌 (Jpn. J. Hyg.) 第 56 巻 第 4 号 2002 年 1 月

Table 1 Number of subjects analyzed with regard to medical expenditure

\begin{tabular}{ccccc}
\hline & \multicolumn{2}{c}{ Examinees (person) } & \multicolumn{2}{c}{ Non-examinees (person) } \\
\hline & Men & Women & Men & Women \\
\hline $1998^{*}$ & 1292 & 2289 & 17513 & 16925 \\
$1999^{*}$ & 1476 & 2510 & 17531 & 17046 \\
\hline
\end{tabular}

* Japanese fiscal year.

Table 2 Basic health checkup examination rate and rate at medical facilities

\begin{tabular}{|c|c|c|c|c|}
\hline & \multicolumn{2}{|c|}{$\begin{array}{l}\text { Basic health checkup } \\
\text { examination rate }(\%)\end{array}$} & \multicolumn{2}{|c|}{$\begin{array}{c}\text { Medical facilities } \\
\text { examination rate }(\%)\end{array}$} \\
\hline & Men & Women & Men & Women \\
\hline $1995^{*}$ & 11.9 & 18.2 & - & - \\
\hline $1996^{*}$ & 13.8 & 20.7 & - & - \\
\hline $1997 *$ & 14.2 & 19.5 & - & - \\
\hline 1998* & 15.6 & 21.1 & 76.5 & 81.4 \\
\hline 1999* & - & - & 82.3 & 87.6 \\
\hline
\end{tabular}

* Japanese fiscal year.

治療，機能訓練等を総合的に行い国民保健の向上と老人 福祉の増進を図ることを目的として, 40 歳以上の地域住 民を対象に保健事業を行うことを定めている。基本健康 診査を地域の保健事業の柱として, その推進に市町村は 力を注ぎ, 1998 年には, 全国で 1000 万人以上が受診す るようになった ${ }^{1)}$ 。基本健康診査の受診率の高い地域で は医療費が低いことが, 以前から, 多くの研究で示され ている ${ }^{2-7)}$ 。しかし, 同一地域内で, 実際の受診者と未受 診者の医療費の比較を複数年度にわたって行った研究は 乏しく,特に人口の多い都市部での研究は見当たらない。 今回我々は, 工業圈の人口約 35 万人の都市に在住する国 民健康保険加入者を対象に, 老人保健法に基づく基本健 康診査の受診の有無と医療費との関連を検討することを 目的として，健診受診者と未受診者の医療費及び生活習 慣等の特性を比較した。

\section{対象と方法}

調査地区は愛知県豊田市である。豊田市は中部地区に 位置する自動車産業を主体とした日本有数の工業都市で ある。また, 愛知県下 2 番目の面積を有し, 工業だけで なく農業も盛んである。人口約 35 万人で, 平成 10 年度
より中核市となった。

この地区に在住する国民健康保険加入者を対象に基 本健康診査受診の有無と医療費・生活習慣等との関連に 関する分析を行った。基本健康診査受診の有無は豊田市 保管の基本健康診査受診者名簿より判定した。各々の分 析において 3 年間連続で健診を受診しているものを健 診受診者, 3 年間連続でいちども健診を受診していない ものを健診未受診者とした。また, 各調查開始年度に基 本健康診査受診資格があるもの（40 歳以上）で，且つ， 2000 年度まで継続して豊田市民であるもののみを対象 者とした。

\section{1. 医療費に関する分析}

医療費は愛知県国民健康保険連合会の国民健康保険レ セプト情報を用いた。結果の再現性を検討するためレセ プト情報は 2 年分を用い, 1995 年度から 3 年間の健診受 診の有無別に 1998 年度の医療費を，また 1996 年度から 3 年間の健診受診の有無別に 1999 年度の医療費を，各々 分析した。各年度に医療機関受診をしていない者の医療 費は 0 とした。各々の対象人数を Table 1 に示す。また各 年度の母集団の基本健康診査受診率と医療機関受診率を Table 2 に示す。各々において, 10 歳ごとの年齢区分別,

\section{Table 3 Living habits score}

\begin{tabular}{lccc}
\hline & 1 point & 2 points & 3 points \\
\hline $\begin{array}{l}\text { Aware of need for exercise in daily life } \\
\text { Habit of periodic exercise over one year }\end{array}$ & Never & Before & Sometimes \\
running over 30 min per time & Never & Once a week & Over twice a week \\
$\begin{array}{l}\text { Smoking habit } \\
\text { Relaxation from sleep }\end{array}$ & Smoker & Ex-smoker & Non-smoker \\
Hobby to release stress & Not enough & Not quite enough & Enough \\
Vegetable intake & No & Yes & - \\
Milk intake & $\leq 25$ percentile & $25 \sim 75$ & - \\
\hline
\end{tabular}


日衛誌 (Jpn. J. Hyg.) 第 56 巻 第 4 号 2002 年 1 月

Table 4 Comparison of medical expenditure of examinees with non-examinees (1998*)

\begin{tabular}{|c|c|c|c|c|c|c|c|c|c|c|c|c|c|c|}
\hline & & \multirow{3}{*}{$\begin{array}{c}\begin{array}{c}\text { Age } \\
\text { classes }\end{array} \\
40 \mathrm{~s}\end{array}$} & \multicolumn{2}{|c|}{ Number of subjects } & \multicolumn{5}{|c|}{ Medical expenditure per case (SD) } & \multicolumn{5}{|c|}{ Medical expenditure per capita (SD) } \\
\hline & & & \multirow{2}{*}{$\begin{array}{c}\text { Examinees } \\
45\end{array}$} & \multirow{2}{*}{$\begin{array}{c}\begin{array}{c}\text { Non- } \\
\text { examinees }\end{array} \\
2190\end{array}$} & \multicolumn{2}{|c|}{ Examinees } & \multicolumn{2}{|c|}{ Non-examinees } & \multirow{2}{*}{$\begin{array}{c}\text { p-value } \\
0.053\end{array}$} & \multicolumn{2}{|c|}{ Examinees } & \multicolumn{2}{|c|}{ Non-examinees } & \multirow{2}{*}{$\begin{array}{c}\text { p-value } \\
<0.01\end{array}$} \\
\hline \multirow{15}{*}{ Men } & \multirow{5}{*}{ All } & & & & 23510 & $(59833)$ & 37967 & (98143) & & 255994 & $(627881)$ & 161629 & $(606918)$ & \\
\hline & & $50 \mathrm{~s}$ & 138 & 3562 & 15416 & $(25640)$ & 41419 & (119807) & $<0.01$ & 160978 & $(166391)$ & 212025 & (774358) & $<0.01$ \\
\hline & & $60 \mathrm{~s}$ & 521 & 7229 & 19784 & (48527) & 35614 & (127584) & $<0.01$ & 366736 & $(497922)$ & 335892 & $(1003642)$ & $<0.01$ \\
\hline & & $70 \mathrm{~s}$ & 502 & 3472 & 30536 & (94426) & 44963 & $(156590)$ & $<0.01$ & 658540 & (1056178) & 781877 & (1994210) & $<0.01$ \\
\hline & & over $80 \mathrm{~s}$ & 86 & 1060 & 35636 & (93891) & 77734 & (281389) & $<0.01$ & 699871 & (936170) & 1424877 & (3897272) & 0.344 \\
\hline & \multirow{5}{*}{$\begin{array}{c}\text { Out- } \\
\text { patients }\end{array}$} & $40 \mathrm{~s}$ & 45 & 2190 & 14648 & $(16528)$ & 19767 & $(43582)$ & 0.820 & 155273 & (159138) & 79403 & $(302727)$ & $<0.01$ \\
\hline & & $50 \mathrm{~s}$ & 138 & 3562 & 14351 & (16570) & 23880 & (59120) & $<0.01$ & 149337 & (139898) & 116308 & (468613) & $<0.01$ \\
\hline & & $60 \mathrm{~s}$ & 521 & 7229 & 16755 & (22948) & 22893 & (72117) & $<0.01$ & 307508 & (380567) & 209116 & (601746) & $<0.01$ \\
\hline & & $70 \mathrm{~s}$ & 502 & 3472 & 21129 & (50013) & 24393 & (59228) & $<0.01$ & 441851 & $(780890)$ & 403633 & (810175) & $<0.01$ \\
\hline & & over 80 s & 86 & 1060 & 20942 & (29240) & 31834 & (110290) & $<0.01$ & 392291 & (406141) & 538347 & (1486443) & 0.034 \\
\hline & \multirow{5}{*}{$\begin{array}{c}\text { In- } \\
\text { patients }\end{array}$} & $40 \mathrm{~s}$ & 45 & 2190 & 348652 & (131899) & 342347 & $(202072)$ & 0.592 & 100722 & $(590015)$ & 82226 & $(507820)$ & 0.847 \\
\hline & & $50 \mathrm{~s}$ & 138 & 3562 & 321284 & (144279) & 385244 & (321055) & 0.889 & 11641 & $(65104)$ & 95716 & (554403) & 0.023 \\
\hline & & $60 \mathrm{~s}$ & 521 & 7229 & 321437 & (305794) & 426856 & (446088) & $<0.01$ & 59228 & (259627) & 126775 & (686980) & 0.229 \\
\hline & & $70 \mathrm{~s}$ & 502 & 3472 & 331639 & $(347981)$ & 449133 & (515558) & $<0.01$ & 216689 & $(665586)$ & 378244 & (1734343) & 0.959 \\
\hline & & over $80 \mathrm{~s}$ & 86 & 1060 & 339127 & (278490) & 624815 & (744209) & $<0.01$ & 307580 & (839730) & 886530 & $(3505602)$ & 0.418 \\
\hline \multirow{15}{*}{ Women } & \multirow{5}{*}{ All } & $40 \mathrm{~s}$ & 72 & 2039 & 15446 & $(35050)$ & 26948 & $(82637)$ & $<0.01$ & 152747 & (216283) & 131516 & $(493284)$ & $<0.01$ \\
\hline & & $50 \mathrm{~s}$ & 363 & 4541 & 16361 & (33049) & 26714 & $(91050)$ & $<0.01$ & 166224 & (252103) & 154880 & $(562671)$ & $<0.01$ \\
\hline & & $60 \mathrm{~s}$ & 1111 & 5401 & 18254 & (54817) & 29444 & (106196) & $<0.01$ & 355956 & (726410) & 370271 & (1128016) & $<0.01$ \\
\hline & & $70 \mathrm{~s}$ & 625 & 3224 & 25891 & $(72555)$ & 49247 & (198710) & $<0.01$ & 610033 & (876706) & 980415 & (2879665) & $<0.01$ \\
\hline & & over 80 s & 118 & 1720 & 42827 & (132777) & 120803 & (408205) & $<0.01$ & 887018 & (1698125) & 2278968 & (5775597) & 0.377 \\
\hline & \multirow{5}{*}{$\begin{array}{c}\text { Out- } \\
\text { patients }\end{array}$} & $40 \mathrm{~s}$ & 72 & 2039 & 13974 & (28203) & 16709 & (32759) & 0.014 & 137409 & $(183467)$ & 79111 & (218242) & $<0.01$ \\
\hline & & $50 \mathrm{~s}$ & 363 & 4541 & 14863 & (22755) & 17712 & (40148) & 0.016 & 150225 & $(224025)$ & 100157 & (330549) & $<0.01$ \\
\hline & & $60 \mathrm{~s}$ & 1111 & 5401 & 15672 & (25774) & 20140 & (43834) & $<0.01$ & 303700 & (411483) & 247797 & (542233) & $<0.01$ \\
\hline & & $70 \mathrm{~s}$ & 625 & 3224 & 19637 & (34778) & 24335 & $(66333)$ & $<0.01$ & 453884 & (466637) & 463126 & (950538) & $<0.01$ \\
\hline & & over 80 s & 118 & 1720 & 23603 & (46009) & 34311 & (123449) & $<0.01$ & 463662 & (571304) & 576890 & (1558893) & $<0.01$ \\
\hline & \multirow{5}{*}{$\begin{array}{c}\text { In- } \\
\text { patients }\end{array}$} & $40 \mathrm{~s}$ & 72 & 2039 & 276095 & (112255) & 359776 & (282823) & 0.711 & 15339 & $(95409)$ & 52405 & (394438) & 0.431 \\
\hline & & $50 \mathrm{~s}$ & 363 & 4541 & 305654 & (171490) & 382894 & (377699) & 0.445 & 15998 & $(91476)$ & 54723 & (436166) & 0.404 \\
\hline & & $60 \mathrm{~s}$ & 1111 & 5401 & 426891 & (454964) & 450600 & (503663) & 0.274 & 52257 & (581776) & 122474 & (928182) & $<0.01$ \\
\hline & & $70 \mathrm{~s}$ & 625 & 3224 & 348546 & $(329702)$ & 589932 & (703801) & $<0.01$ & 156149 & (707514) & 517288 & (2628422) & $<0.01$ \\
\hline & & over 80 s & 118 & 1720 & 396477 & $(415207)$ & 829577 & (918567) & $<0.01$ & 423356 & (1416343) & 1702079 & (5469681) & 0.011 \\
\hline
\end{tabular}

\begin{tabular}{|c|c|c|c|c|c|c|c|c|c|c|c|c|c|c|c|c|c|}
\hline & & \multirow{3}{*}{$\begin{array}{c}\begin{array}{c}\text { Age } \\
\text { classes }\end{array} \\
40 \mathrm{~s}\end{array}$} & \multicolumn{5}{|c|}{ Medical expenditure per day (SD) } & \multicolumn{5}{|c|}{ Number of examination days per case (SD) } & \multicolumn{5}{|c|}{ Examination rate (SD) } \\
\hline & & & \multicolumn{2}{|c|}{ Examinees } & \multicolumn{2}{|c|}{ Non-examinees } & \multirow{2}{*}{$\begin{array}{c}\text { p-value } \\
<0.01\end{array}$} & \multicolumn{2}{|c|}{ Examinees } & \multicolumn{2}{|c|}{ Non-examinees } & \multirow{2}{*}{$\frac{\text { p-value }}{0.373}$} & \multicolumn{2}{|c|}{ Examinees } & \multicolumn{2}{|c|}{ Non-examinees } & \multirow{2}{*}{$\frac{p \text {-value }}{<0.01}$} \\
\hline \multirow{15}{*}{ Men } & \multirow{5}{*}{ All } & & 6963 & $(4749)$ & 9040 & $(12173)$ & & 2.9 & $(4.5)$ & 3.5 & $(6.1)$ & & 10.9 & $(9.7)$ & 4.3 & $(6.4)$ & \\
\hline & & $50 \mathrm{~s}$ & 7392 & $(5730)$ & 10184 & $(16653)$ & $<0.01$ & 2.2 & $(2.1)$ & 3.4 & $(5.6)$ & $<0.01$ & 10.4 & $(7.8)$ & 5.1 & $(7.2)$ & $<0.01$ \\
\hline & & $60 \mathrm{~s}$ & 7608 & $(10831)$ & 10834 & (49967) & $<0.01$ & 2.8 & (3.4) & 2.9 & (4.3) & $<0.01$ & 18.5 & $(15.9)$ & 9.4 & $(12.3)$ & $<0.01$ \\
\hline & & $70 \mathrm{~s}$ & 9060 & $(16183)$ & 11552 & (19645) & $<0.01$ & 3.0 & (4.0) & 3.2 & (5.0) & $<0.01$ & 21.6 & $(15.3)$ & 17.4 & (13.9) & $<0.01$ \\
\hline & & over 80 s & 8302 & (10181) & 14033 & (24305) & $<0.01$ & 3.6 & (5.1) & 3.7 & (5.8) & 0.816 & 19.6 & (12.7) & 18.3 & (12.6) & 0.339 \\
\hline & \multirow{5}{*}{$\begin{array}{c}\text { Out- } \\
\text { patients }\end{array}$} & $40 \mathrm{~s}$ & 6781 & $(4654)$ & 8420 & $(10338)$ & 0.097 & 2.3 & $(2.1)$ & 2.3 & (2.7) & 0.226 & 10.6 & $(9.5)$ & 4.0 & $(6.2)$ & $<0.01$ \\
\hline & & $50 \mathrm{~s}$ & 7307 & (5516) & 9593 & (15983) & $<0.01$ & 2.2 & (2.1) & 2.4 & (2.7) & 0.338 & 10.4 & (7.8) & 4.9 & $(6.9)$ & $<0.01$ \\
\hline & & $60 \mathrm{~s}$ & 7292 & (9658) & 10125 & $(49665)$ & $<0.01$ & 2.7 & (3.2) & 2.4 & $(2.8)$ & $<0.01$ & 18.4 & (15.7) & 9.1 & $(12.0)$ & $<0.01$ \\
\hline & & $70 \mathrm{~s}$ & 8280 & (14685) & 10544 & (18417) & $<0.01$ & 2.7 & (3.4) & 2.5 & (3.3) & $<0.01$ & 20.9 & $(15.0)$ & 16.5 & $(13.4)$ & $<0.01$ \\
\hline & & over $80 \mathrm{~s}$ & 7274 & $(8405)$ & 12014 & (21232) & $<0.01$ & 3.1 & (4.4) & 2.6 & (3.4) & $<0.01$ & 18.7 & (12.0) & 16.9 & (12.1) & 0.163 \\
\hline & \multirow{5}{*}{$\begin{array}{c}\text { In- } \\
\text { patients }\end{array}$} & $40 \mathrm{~s}$ & 13567 & $(3362)$ & 19396 & (26930) & 0.075 & 26.0 & $(7.8)$ & 23.5 & $(10.4)$ & 0.097 & 0.3 & $(1.6)$ & 0.2 & $(1.4)$ & 0.822 \\
\hline & & $50 \mathrm{~s}$ & 31719 & (12704) & 21741 & (23776) & 0.072 & 10.2 & (3.9) & 22.8 & $(10.4)$ & 0.059 & 0.0 & $(0.2)$ & 0.2 & (1.4) & $<0.01$ \\
\hline & & $60 \mathrm{~s}$ & 39022 & (39111) & 32585 & (54141) & 0.073 & 10.8 & (9.1) & 17.8 & (11.2) & $<0.01$ & 0.2 & $(0.8)$ & 0.3 & (1.4) & $<0.01$ \\
\hline & & $70 \mathrm{~s}$ & 33736 & (33169) & 31090 & (29853) & $<0.01$ & 11.4 & (8.7) & 16.0 & $(10.8)$ & $<0.01$ & 0.7 & (1.6) & 0.8 & (2.6) & 0.039 \\
\hline & & over $80 \mathrm{~s}$ & 28935 & (17968) & 37842 & $(40327)$ & 0.097 & 12.7 & (8.7) & 16.9 & $(10.5)$ & $<0.01$ & 0.9 & $(2.0)$ & 1.4 & (3.6) & 0.047 \\
\hline \multirow{15}{*}{ Women } & \multirow{5}{*}{ All } & $40 \mathrm{~s}$ & 6946 & $(6195)$ & 7908 & $(8686)$ & 0.028 & 2.1 & (2.3) & 2.8 & $(4.6)$ & $<0.01$ & 9.9 & $(10.0)$ & 4.9 & (6.8) & $<0.01$ \\
\hline & & $50 \mathrm{~s}$ & 6655 & $(6221)$ & 8132 & (9973) & $<0.01$ & 2.4 & $(2.7)$ & 2.7 & $(4.2)$ & 0.886 & 10.2 & $(9.7)$ & 5.8 & $(7.9)$ & $<0.01$ \\
\hline & & $60 \mathrm{~s}$ & 6767 & (9404) & 9040 & $(16048)$ & $<0.01$ & 2.6 & (3.2) & 2.8 & $(4.1)$ & 0.713 & 19.5 & $(16.2)$ & 12.6 & $(14.1)$ & $<0.01$ \\
\hline & & $70 \mathrm{~s}$ & 8254 & (18936) & 10881 & (20032) & $<0.01$ & 2.8 & (3.6) & 3.1 & $(4.9)$ & 0.224 & 23.6 & (13.8) & 19.9 & (13.9) & $<0.01$ \\
\hline & & over 80 s & 8806 & $(13456)$ & 14093 & $(30742)$ & $<0.01$ & 3.8 & $(5.4)$ & 4.7 & $(7.5)$ & $<0.01$ & 20.7 & $(10.7)$ & 18.9 & $(12.4)$ & 0.045 \\
\hline & \multirow{5}{*}{$\begin{array}{c}\text { Out- } \\
\text { patients }\end{array}$} & $40 \mathrm{~s}$ & 6790 & (5699) & 7489 & $(7645)$ & 0.176 & 2.1 & (2.2) & 2.2 & (2.4) & 0.043 & 9.8 & $(10.0)$ & 4.7 & $(6.7)$ & $<0.01$ \\
\hline & & $50 \mathrm{~s}$ & 6508 & (5577) & 7752 & (8739) & $<0.01$ & 2.4 & (2.6) & 2.2 & (2.4) & $<0.01$ & 10.1 & $(9.6)$ & 5.7 & $(7.8)$ & $<0.01$ \\
\hline & & $60 \mathrm{~s}$ & 6585 & $(8412)$ & 8585 & (14990) & $<0.01$ & 2.5 & (2.9) & 2.5 & $(2.9)$ & $<0.01$ & 19.4 & $(16.2)$ & 12.3 & (13.9) & $<0.01$ \\
\hline & & $70 \mathrm{~s}$ & 7779 & (17902) & 9744 & (18038) & $<0.01$ & 2.6 & (3.1) & 2.4 & (2.9) & $<0.01$ & 23.1 & (13.6) & 19.0 & (13.6) & $<0.01$ \\
\hline & & over 80 s & 7685 & (11901) & 10997 & $(22310)$ & $<0.01$ & 3.2 & $(4.4)$ & 2.6 & (3.2) & $<0.01$ & 19.6 & $(10.5)$ & 16.8 & (12.3) & $<0.01$ \\
\hline & \multirow{5}{*}{$\begin{array}{c}\text { In- } \\
\text { patients }\end{array}$} & $40 \mathrm{~s}$ & 34528 & (20477) & 21494 & (20919) & 0.056 & 10.5 & (8.6) & 22.3 & (10.9) & 0.083 & 0.1 & $(0.3)$ & 0.1 & $(1.0)$ & 0.057 \\
\hline & & $50 \mathrm{~s}$ & 35041 & (27094) & 23137 & (27964) & $<0.01$ & 11.0 & $(7.1)$ & 22.0 & (10.6) & $<0.01$ & 0.1 & $(0.3)$ & 0.1 & $(1.0)$ & $<0.01$ \\
\hline & & $60 \mathrm{~s}$ & 35489 & $(45452)$ & 29595 & $(36230)$ & $<0.01$ & 15.6 & (11.6) & 19.4 & $(11.2)$ & $<0.01$ & 0.1 & (0.9) & 0.3 & (1.5) & $<0.01$ \\
\hline & & $70 \mathrm{~s}$ & 32315 & (41286) & 35126 & (37491) & 0.495 & 13.3 & $(9.4)$ & 18.2 & (11.1) & $<0.01$ & 0.4 & (1.7) & 0.9 & (3.0) & $<0.01$ \\
\hline & & over $80 \mathrm{~s}$ & 29026 & $(21555)$ & 39003 & $(62032)$ & 0.373 & 14.7 & (9.6) & 21.6 & $(10.4)$ & $<0.01$ & 1.1 & (2.9) & 2.1 & (4.9) & $<0.01$ \\
\hline
\end{tabular}


日衛誌 (Jpn. J. Hyg.) 第 56 巻 第 4 号 2002 年 1 月

Table 5 Comparison of medical expenditure of examinees with non-examinees (1999*)

\begin{tabular}{|c|c|c|c|c|c|c|c|c|c|c|c|c|c|c|}
\hline & & \multirow{3}{*}{$\begin{array}{c}\begin{array}{c}\text { Age } \\
\text { classes }\end{array} \\
\\
40 \mathrm{~s}\end{array}$} & \multicolumn{2}{|c|}{ Number of subjects } & \multicolumn{5}{|c|}{ Medical expenditure per case (SD) } & \multicolumn{5}{|c|}{ Medical expenditure per capita (SD) } \\
\hline & & & \multirow{2}{*}{$\begin{array}{c}\text { Examinees } \\
37\end{array}$} & \multirow{2}{*}{$\begin{array}{c}\begin{array}{c}\text { Non- } \\
\text { examinees }\end{array} \\
2053\end{array}$} & \multicolumn{2}{|c|}{ Examinees } & \multicolumn{2}{|c|}{ Non-examinees } & \multirow{2}{*}{$\begin{array}{c}\text { p-value } \\
<0.01\end{array}$} & \multicolumn{2}{|c|}{ Examinees } & \multicolumn{2}{|c|}{ Non-examinees } & \multirow{2}{*}{$\begin{array}{c}\text { p-value } \\
0.041\end{array}$} \\
\hline \multirow{15}{*}{ Men } & \multirow{5}{*}{ All } & & & & 13206 & $(24468)$ & 32964 & $(101858)$ & & 124565 & $(175360)$ & 153771 & $(610890)$ & \\
\hline & & $50 \mathrm{~s}$ & 148 & 3504 & 15451 & $(40503)$ & 40935 & (126544) & $<0.01$ & 180508 & (230909) & 260646 & (864547) & $<0.01$ \\
\hline & & $60 \mathrm{~s}$ & 586 & 6881 & 21524 & $(85383)$ & 34521 & (120577) & $<0.01$ & 454866 & (950443) & 421420 & (1197886) & $<0.01$ \\
\hline & & $70 \mathrm{~s}$ & 573 & 3817 & 29813 & $(114107)$ & 49106 & $(183692)$ & $<0.01$ & 728613 & $(1476336)$ & 1010789 & $(2608076)$ & $<0.01$ \\
\hline & & over $80 \mathrm{~s}$ & 132 & 1276 & 40761 & (137905) & 76997 & $(284249)$ & $<0.01$ & 977653 & (2298366) & 1672565 & $(4189980)$ & 0.503 \\
\hline & \multirow{5}{*}{$\begin{array}{c}\text { Out- } \\
\text { patients }\end{array}$} & $40 \mathrm{~s}$ & 37 & 2053 & 12058 & (11796) & 19182 & $(43740)$ & $<0.01$ & 113411 & (144024) & 85782 & (323264) & 0.015 \\
\hline & & $50 \mathrm{~s}$ & 148 & 3504 & 13003 & (17136) & 22188 & (57026) & $<0.01$ & 150587 & (162178) & 134402 & (504063) & $<0.01$ \\
\hline & & $60 \mathrm{~s}$ & 586 & 6881 & 17087 & (58745) & 21703 & (61754) & $<0.01$ & 357131 & (576245) & 256873 & (703187) & $<0.01$ \\
\hline & & $70 \mathrm{~s}$ & 573 & 3817 & 19687 & (44968) & 23554 & $(68490)$ & 0.027 & 467813 & (723994) & 459613 & (967503) & $<0.01$ \\
\hline & & over $80 \mathrm{~s}$ & 132 & 1276 & 21079 & $(36890)$ & 29235 & (102080) & $<0.01$ & 480188 & (540795) & 585256 & (1459062) & $<0.01$ \\
\hline & \multirow{5}{*}{$\begin{array}{c}\text { In- } \\
\text { patients }\end{array}$} & $40 s$ & 37 & 2053 & 412700 & $(-)$ & 352479 & (316693) & - & 11154 & $(67848)$ & 67989 & $(472314)$ & 0.335 \\
\hline & & $50 \mathrm{~s}$ & 148 & 3504 & 295214 & $(286289)$ & 407328 & $(352726)$ & 0.096 & 29920 & (149910) & 126244 & (653496) & 0.101 \\
\hline & & $60 \mathrm{~s}$ & 586 & 6881 & 421125 & (439311) & 442628 & (429312) & 0.094 & 97736 & (696974) & 164546 & (895042) & 0.312 \\
\hline & & $70 \mathrm{~s}$ & 573 & 3817 & 385150 & (519404) & 514637 & (578368) & $<0.01$ & 260800 & (1265190) & 551176 & (2338596) & 0.036 \\
\hline & & over 80 s & 132 & 1276 & 412990 & (456357) & 638181 & (752472) & $<0.01$ & 497465 & (2216649) & 1087309 & (3865568) & 0.042 \\
\hline \multirow{15}{*}{ Women } & \multirow{5}{*}{ All } & $40 \mathrm{~s}$ & 76 & 1887 & 16733 & $(43143)$ & 27685 & $(82502)$ & $<0.01$ & 154340 & $(297684)$ & 149063 & (493634) & $<0.01$ \\
\hline & & $50 \mathrm{~s}$ & 385 & 4168 & 17234 & (60849) & 26374 & $(88473)$ & $<0.01$ & 223018 & (361196) & 203794 & (613829) & $<0.01$ \\
\hline & & $60 \mathrm{~s}$ & 1163 & 5589 & 17892 & (52892) & 27980 & (105387) & $<0.01$ & 397146 & (586711) & 420805 & (1224421) & $<0.01$ \\
\hline & & $70 \mathrm{~s}$ & 736 & 3474 & 26374 & (87014) & 51198 & (220257) & $<0.01$ & 709298 & (1273950) & 1161054 & (3486735) & $<0.01$ \\
\hline & & over 80 s & 150 & 1928 & 44576 & (207284) & 136508 & (443864) & $<0.01$ & 1054960 & (3268250) & 2903556 & (6753552) & 0.373 \\
\hline & \multirow{5}{*}{$\begin{array}{c}\text { Out- } \\
\text { patients }\end{array}$} & $40 \mathrm{~s}$ & 76 & 1887 & 13203 & (16204) & 16709 & $(34218)$ & 0.225 & 120568 & $(154740)$ & 87111 & $(245144)$ & $<0.01$ \\
\hline & & $50 \mathrm{~s}$ & 385 & 4168 & 13919 & (24384) & 17364 & (38583) & $<0.01$ & 178704 & (238334) & 130942 & (362505) & $<0.01$ \\
\hline & & $60 \mathrm{~s}$ & 1163 & 5589 & 15570 & (27049) & 18213 & (40877) & $<0.01$ & 343417 & (476675) & 267945 & $(551620)$ & $<0.01$ \\
\hline & & $70 \mathrm{~s}$ & 736 & 3474 & 19699 & (51193) & 23651 & (76719) & $<0.01$ & 519931 & (786973) & 512970 & (1176619) & $<0.01$ \\
\hline & & over 80 s & 150 & 1928 & 18724 & (31840) & 37077 & (137929) & $<0.01$ & 423529 & (419887) & 698407 & (1869944) & $<0.01$ \\
\hline & \multirow{5}{*}{$\begin{array}{c}\text { In- } \\
\text { patients }\end{array}$} & $40 \mathrm{~s}$ & 76 & 1887 & 366669 & (206198) & 363056 & (251027) & 0.948 & 33772 & (221325) & 61952 & $(406858)$ & 0.671 \\
\hline & & $50 \mathrm{~s}$ & 385 & 4168 & 437454 & (474696) & 391800 & (358095) & 0.559 & 44314 & (249100) & 72852 & (456875) & 0.735 \\
\hline & & $60 \mathrm{~s}$ & 1163 & 5589 & 383359 & (441246) & 466596 & (488147) & $<0.01$ & 53730 & (321786) & 152860 & (1013163) & $<0.01$ \\
\hline & & $70 \mathrm{~s}$ & 736 & 3474 & 378733 & (377864) & 655252 & (775836) & $<0.01$ & 189367 & (908991) & 648085 & (3176824) & $<0.01$ \\
\hline & & over 80 s & 150 & 1928 & 603279 & (791683) & 906123 & (951852) & $<0.01$ & 631432 & (3234883) & 2205149 & $(6311227)$ & $<0.01$ \\
\hline
\end{tabular}

\begin{tabular}{|c|c|c|c|c|c|c|c|c|c|c|c|c|c|c|c|c|c|}
\hline & & \multirow{3}{*}{$\begin{array}{c}\begin{array}{c}\text { Age } \\
\text { classes }\end{array} \\
40 \mathrm{~s}\end{array}$} & \multicolumn{5}{|c|}{ Medical expenditure per day (SD) } & \multicolumn{5}{|c|}{ Number of examination days per case (SD) } & \multicolumn{5}{|c|}{ Examination rate $(\mathrm{SD})$} \\
\hline & & & \multicolumn{2}{|c|}{ Examinees } & \multicolumn{2}{|c|}{ Non-examinees } & \multirow{2}{*}{$\frac{p \text {-value }}{<0.01}$} & \multicolumn{2}{|c|}{ Examinees } & \multicolumn{2}{|c|}{ Non-examinees } & \multirow{2}{*}{$\begin{array}{c}\text { p-value } \\
0.605\end{array}$} & \multicolumn{2}{|c|}{ Examinees } & \multicolumn{2}{|c|}{ Non-examinees } & \multirow{2}{*}{$\begin{array}{r}\text { p-valu } \\
0.017\end{array}$} \\
\hline \multirow{15}{*}{ Men } & \multirow{5}{*}{ All } & & 6428 & $(4727)$ & 8900 & $(11448)$ & & 2.3 & $(2.2)$ & 3.1 & $(5.1)$ & & 9.4 & $(11.8)$ & 4.7 & $(7.9)$ & \\
\hline & & $50 \mathrm{~s}$ & 7152 & $(6314)$ & 9981 & (14843) & $<0.01$ & 2.0 & $(2.1)$ & 3.3 & $(5.7)$ & $<0.01$ & 11.7 & $(10.5)$ & 6.4 & $(8.7)$ & $<0.01$ \\
\hline & & $60 \mathrm{~s}$ & 8061 & (49118) & 10403 & $(35920)$ & $<0.01$ & 2.7 & (3.4) & 2.8 & (4.3) & $<0.01$ & 21.1 & (18.8) & 12.2 & (14.5) & $<0.01$ \\
\hline & & $70 \mathrm{~s}$ & 9194 & (19570) & 11288 & (19260) & $<0.01$ & 2.8 & (3.7) & 3.2 & (5.1) & 0.162 & 24.4 & (17.9) & 20.6 & (16.8) & $<0.01$ \\
\hline & & over 80 s & 9543 & (20000) & 13254 & (25355) & $<0.01$ & 3.5 & (5.2) & 3.6 & $(6.0)$ & 0.388 & 24.0 & (16.4) & 21.7 & (15.2) & 0.115 \\
\hline & \multirow{5}{*}{$\begin{array}{c}\text { Out- } \\
\text { patients }\end{array}$} & $40 \mathrm{~s}$ & 6282 & $(4375)$ & 8367 & (10583) & $<0.01$ & 2.3 & (1.9) & 2.3 & (2.7) & 0.046 & 9.4 & $(11.8)$ & 4.5 & $(7.6)$ & 0.014 \\
\hline & & $50 \mathrm{~s}$ & 6959 & (5627) & 9246 & (13099) & $<0.01$ & 2.0 & (2.0) & 2.3 & (2.7) & $<0.01$ & 11.6 & (10.4) & 6.1 & (8.4) & $<0.01$ \\
\hline & & $60 \mathrm{~s}$ & 7661 & (49279) & 9652 & (35315) & $<0.01$ & 2.5 & (3.1) & 2.3 & $(2.8)$ & $<0.01$ & 20.9 & (18.6) & 11.8 & (14.2) & $<0.01$ \\
\hline & & $70 \mathrm{~s}$ & 8277 & (17702) & 10016 & (17486) & $<0.01$ & 2.5 & (3.1) & 2.4 & (3.1) & $<0.01$ & 23.8 & (17.6) & 19.5 & (16.3) & $<0.01$ \\
\hline & & over 80 s & 8390 & (18988) & 11087 & (19307) & $<0.01$ & 2.9 & (3.9) & 2.4 & (3.2) & $<0.01$ & 22.8 & (16.2) & 20.0 & (14.9) & 0.048 \\
\hline & \multirow{5}{*}{$\begin{array}{c}\text { In- } \\
\text { patients }\end{array}$} & $40 \mathrm{~s}$ & 23734 & (11187) & 20176 & (20032) & - & 21.0 & $(-)$ & 21.2 & (11.3) & - & 0.0 & $(0.2)$ & 0.2 & $(1.3)$ & $<0.01$ \\
\hline & & $50 \mathrm{~s}$ & 34095 & (22166) & 25383 & (31525) & 0.473 & 9.1 & (6.7) & 23.5 & (10.3) & $<0.01$ & 0.1 & $(0.4)$ & 0.3 & (1.5) & $<0.01$ \\
\hline & & $60 \mathrm{~s}$ & 35998 & (22700) & 33716 & (45475) & $<0.01$ & 12.4 & (9.9) & 17.8 & (11.2) & $<0.01$ & 0.2 & (0.9) & 0.4 & (1.7) & $<0.01$ \\
\hline & & $70 \mathrm{~s}$ & 37331 & (41307) & 32894 & (31374) & $<0.01$ & 11.5 & $(9.5)$ & 17.1 & (11.0) & $<0.01$ & 0.7 & $(2.0)$ & 1.1 & (3.2) & $<0.01$ \\
\hline & & over $80 \mathrm{~s}$ & 31052 & (25551) & 38463 & (55638) & 0.340 & 14.7 & (10.4) & 17.8 & (10.9) & $<0.01$ & 1.2 & (3.8) & 1.7 & $(4.0)$ & 0.150 \\
\hline \multirow{15}{*}{ Women } & \multirow{5}{*}{ All } & $40 \mathrm{~s}$ & 7182 & (7117) & 7933 & $(8869)$ & 0.259 & 2.1 & $(2.5)$ & 2.9 & $(4.8)$ & $<0.01$ & 9.2 & $(10.1)$ & 5.4 & (7.3) & $<0.01$ \\
\hline & & $50 \mathrm{~s}$ & 6428 & (6459) & 8003 & (10174) & $<0.01$ & 2.3 & (2.6) & 2.7 & $(4.1)$ & $<0.01$ & 12.9 & (10.7) & 7.7 & (9.3) & $<0.01$ \\
\hline & & $60 \mathrm{~s}$ & 6778 & (17891) & 8828 & (14537) & $<0.01$ & 2.6 & (3.1) & 2.6 & (3.9) & $<0.01$ & 22.2 & (17.8) & 15.0 & (16.2) & $<0.01$ \\
\hline & & $70 \mathrm{~s}$ & 8123 & (16696) & 10745 & (22014) & $<0.01$ & 2.7 & (3.6) & 3.1 & (5.0) & 0.658 & 26.9 & (16.8) & 22.7 & (16.5) & $<0.01$ \\
\hline & & over $80 \mathrm{~s}$ & 8363 & (15174) & 14884 & (29039) & $<0.01$ & 3.4 & (5.3) & 4.7 & (7.5) & $<0.01$ & 23.7 & (13.2) & 21.3 & (14.3) & 0.032 \\
\hline & \multirow{5}{*}{$\begin{array}{c}\text { Out- } \\
\text { patients }\end{array}$} & $40 \mathrm{~s}$ & 6911 & $(6580)$ & 7447 & $(7650)$ & 0.610 & 2.0 & $(1.8)$ & 2.2 & (2.4) & 0.128 & 9.1 & $(10.0)$ & 5.2 & $(7.1)$ & $<0.01$ \\
\hline & & $50 \mathrm{~s}$ & 6165 & (4918) & 7605 & (9011) & $<0.01$ & 2.2 & (2.3) & 2.2 & (2.4) & 0.253 & 12.8 & $(10.6)$ & 7.5 & (9.1) & $<0.01$ \\
\hline & & $60 \mathrm{~s}$ & 6504 & (13003) & 8263 & (13024) & $<0.01$ & 2.5 & (2.9) & 2.3 & (2.7) & $<0.01$ & 22.1 & (17.7) & 14.7 & (16.0) & $<0.01$ \\
\hline & & $70 \mathrm{~s}$ & 7631 & (16005) & 9305 & (19103) & $<0.01$ & 2.5 & (3.0) & 2.4 & (2.9) & $<0.01$ & 26.4 & (16.4) & 21.7 & (16.2) & $<0.01$ \\
\hline & & over $80 \mathrm{~s}$ & 7184 & (12924) & 11105 & (23138) & $<0.01$ & 2.8 & (3.8) & 2.5 & $(3.0)$ & $<0.01$ & 22.6 & (13.1) & 18.8 & (14.3) & $<0.01$ \\
\hline & \multirow{5}{*}{$\begin{array}{c}\text { In- } \\
\text { patients }\end{array}$} & $40 \mathrm{~s}$ & 29545 & (12927) & 22614 & (21556) & 0.023 & 16.0 & (11.7) & 23.5 & $(10.2)$ & 0.090 & 0.1 & $(0.5)$ & 0.2 & $(1.1)$ & 0.250 \\
\hline & & $50 \mathrm{~s}$ & 38152 & (34165) & 25393 & (27731) & $<0.01$ & 12.6 & $(9.4)$ & 21.1 & (11.0) & $<0.01$ & 0.1 & $(0.5)$ & 0.2 & (1.1) & $<0.01$ \\
\hline & & $60 \mathrm{~s}$ & 45925 & (142889) & 32335 & (37158) & $<0.01$ & 11.7 & $(9.4)$ & 18.3 & (11.2) & $<0.01$ & 0.1 & $(0.7)$ & 0.3 & (1.7) & $<0.01$ \\
\hline & & $70 \mathrm{~s}$ & 30905 & (28228) & 38659 & (44547) & 0.095 & 14.2 & (10.4) & 18.8 & (11.0) & $<0.01$ & 0.5 & $(1.8)$ & 1.0 & (3.3) & $<0.01$ \\
\hline & & over $80 \mathrm{~s}$ & 33568 & (30371) & 43661 & (47448) & 0.242 & 17.5 & (11.0) & 21.4 & $(10.5)$ & $<0.01$ & 1.0 & (3.2) & 2.4 & (5.3) & $<0.01$ \\
\hline
\end{tabular}

* Japanese fiscal year. 
男女別，外来入院別に 1 件当たり医療費， 1 人当たり医 療費，1日当たり医療費， 1 件当たり受診日数，受診率 （1 人当たりレセプト枚数）を健診受診者と健診未受診者 で比較した。

\section{2. 生活習慣等に関する分析}

生活習慣等に関する分析には，著者が市より委嘱され て 2000 年 11 月に豊田市で行った市民生活実態調查（成 人版）のデータを用いた。調査は住民基本台帳より性別・ 5 歳毎の年齢区分別に層別に無作為抽出した 20 歳から 89 歳までの市民 2100 人を対象に行った。質問紙は, 調 查員の家庭訪問によって配布・回収した。回収率は 89.3 \%であった。対象者からは各人の医療費，健診データを 利用する旨のインフォームドコンセントを得た。調查に 回答の得られた, 1997 年度から 3 年間の健診受診者, 女 性 37 名（平均年齢 $70.9 \pm 8.01$ 歳），男性 30 名（平均年 齢 74. $6 \pm 7.65$ 歳）を対象とした。また調査に回答の得ら れた健診未受診者の中から年齢・性別を対象とマッチし て無作為抽出で 3 倍の人数のコントロールを選び, 両群 の比較を行った。調査には，食事・運動・睡眠・喫煙な どの生活習慣, 歯科に関すること, 仕事ストレス, 疲労・ 不安・抑うつなどの心身症状, がん等各健診受診の有無, 既往歴・現病歴, 体力・健康度の自己評価, 健康知識, 病休日数, 地域活動参加状況などの質問紙項目のほか, 万歩計による実際の歩数測定，献立書き出しによる食事 調査等が含まれていた。各栄養素・食品量は, 全食事量 による偏りをなくすため, 各人のエネルギー量で各々の 栄養素・食品量を割ったもの $(\times 1000)$ を分析に用いた。 生活習慣指数は運動習慣に関する設問より 7 点，野菜や 乳類の摄取量により 6 点, 喫煙習慣の有無により 3 点, 休養・ストレスに関する設問より 5 点の計 21 点を各々加 算して求めた (Table 3)。

有意性の検定は以下のように行った。医療費に関する 分析における受診群と未受診群の医療費, 受診日数, 受 診率等の比較には，より正規分布に近くなるように原点 変換と対数変換を行った上で $\mathrm{t}$ 検定を用い，年齢による 医療費の変化の分析には年代，受診未受診別，および両 者の交互作用を変数とした分散分析を行った。生活習慣 等に関する分析における受診群と未受診群の生活習慣の 率の比較にはカイ二乗検定を用い，両群の生活習慣指数 の比較には $\mathrm{t}$ 検定を使用した。以上の解析には Windows 版 SAS システムVer. 6.12 を使用した。

\section{結果}

\section{1. 医療費に関する分析}

外来医療費では， 1 件当たり医療費は，健診未受診者 に比べ健診受診者の方がほとんどすべての年齢区分で有 意に低く,その差は高年齢区分になるほど大きくなった。 1 人当たり医療費は, 若年では有意に健診受診者の方が 高いが，高齢になると逆転し，80歳代以降は健診受診者

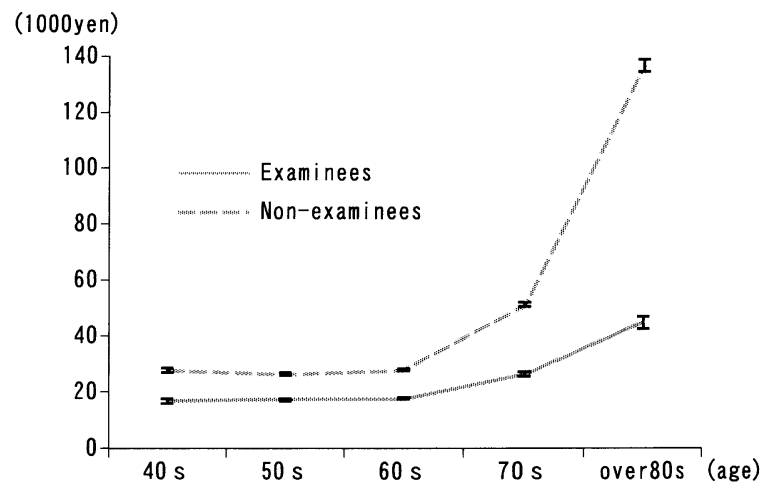

Fig. 1 Medical expenditure per case (1999* women, all).

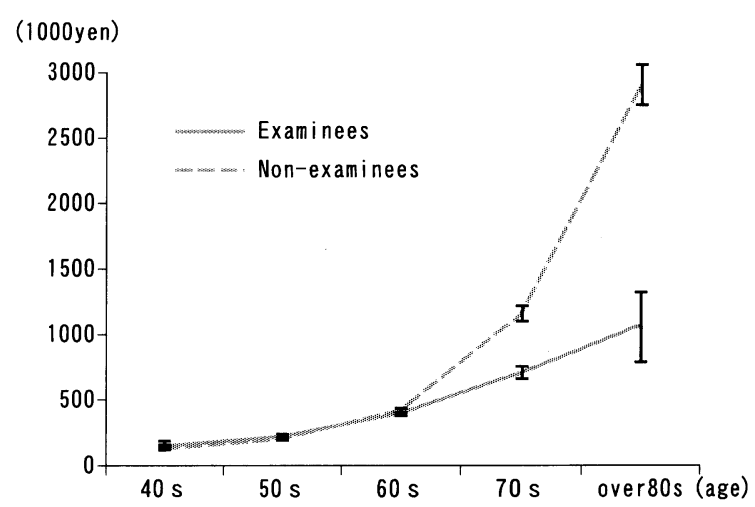

Fig. 2 Medical expenditure per capita (1999* women, all).

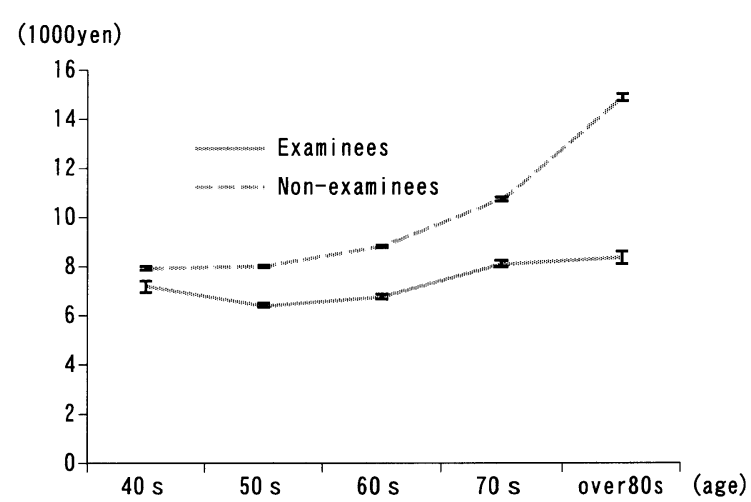

Fig. 3 Medical expenditure per day (1999* women, all).

The increase in medical expenditure with age was less in the basic health checkup examinees than in the non-examinees $(p<0.01)$. * Japanese fiscal year

の方が低くなった。1日当たり医療費は全年齢区分で健 診受診者の方が低かった。1件当たり受診日数は 40 歳代 では健診未受診者の方が多いが，50 から 60 歳代以降は 健診受診者の方が多くなった。受診率はほとんどすべて の年齢区分で健診受診者の方が高いが，その差は高齢に なるほど小さくなった（Table 4,5）。

入院医療費では，1998 年度の 40 歳代男性，1999 年度 の 40 歳代男性と 40 歳代, 50 歳代女性を除く全年齢区分 で健診受診者は 1 件当たり医療費が低かった。健診受診 
Table 6 Comparison of living habits of examinees with non-examinees

\begin{tabular}{|c|c|c|c|c|c|c|c|}
\hline & & \multicolumn{3}{|c|}{ Men } & \multicolumn{3}{|c|}{ Women } \\
\hline & & Examinees & $\begin{array}{l}\text { Non- } \\
\text { examinees }\end{array}$ & p-value & Examinees & $\begin{array}{l}\text { Non- } \\
\text { examinees }\end{array}$ & p-value \\
\hline Intending to keep ideal body weight & & $75.86 \%$ & $58.62 \%$ & 0.096 & $75.00 \%$ & $72.55 \%$ & 0.775 \\
\hline Normal level of own generation in physical strength & & $60 \%$ & $29.21 \%$ & 0.010 & $62.16 \%$ & $52.34 \%$ & 0.565 \\
\hline $\begin{array}{l}\text { Doing periodic exercise over one year running over } \\
30 \text { min per time }\end{array}$ & & $70.37 \%$ & $41.46 \%$ & 0.009 & $51.43 \%$ & $47.96 \%$ & 0.724 \\
\hline \multirow[t]{2}{*}{$\begin{array}{l}\text { Pedmeter count } \\
\text { (SD) }\end{array}$} & weekday & $\begin{array}{c}7113.3 \\
(4339.3)\end{array}$ & $\begin{array}{c}5097.8 \\
(4700.6)\end{array}$ & 0.072 & $\begin{array}{c}5076.3 \\
(3048.4)\end{array}$ & $\begin{array}{c}5683.0 \\
(4546.3)\end{array}$ & 0.405 \\
\hline & holiday & $\begin{array}{c}7271.7 \\
(4181.5)\end{array}$ & $\begin{array}{c}4643.2 \\
(4171.8)\end{array}$ & 0.011 & $\begin{array}{c}4650.8 \\
(2727.3)\end{array}$ & $\begin{array}{c}5565.0 \\
(4266.3)\end{array}$ & 0.176 \\
\hline Periodic dental health checkups & & $42.31 \%$ & $23.75 \%$ & 0.068 & $35.48 \%$ & $27.62 \%$ & 0.398 \\
\hline \multirow[t]{3}{*}{ Cancer checkup in the last year } & stomach & $52.17 \%$ & $23.81 \%$ & 0.012 & $60.00 \%$ & $24.14 \%$ & 0.001 \\
\hline & intestines & $52.38 \%$ & $16.67 \%$ & 0.001 & $63.33 \%$ & $16.67 \%$ & 0.001 \\
\hline & lungs & $61.90 \%$ & $16.07 \%$ & 0.001 & $65.52 \%$ & $20.73 \%$ & 0.001 \\
\hline Anxiety score (SD) & & $4.28(1.40)$ & $5.12(2.20)$ & 0.034 & $5.38(1.86)$ & $4.88(1.90)$ & 0.216 \\
\hline Depression score (SD) & & $8.08(2.60)$ & $9.42(3.84)$ & 0.060 & $9.47(3.31)$ & $9.13(3.79)$ & 0.670 \\
\hline \multirow[t]{5}{*}{ Nutriment intake and food group intake (SD) } & calcium & $275.1(92.1)$ & $223.8(78.3)$ & 0.008 & $284.0(87.7)$ & $270.0(91.1)$ & 0.434 \\
\hline & dietary fiber & $7.88(1.60)$ & $6.59(1.82)$ & 0.002 & $7.65(1.74)$ & $7.68(1.92)$ & 0.951 \\
\hline & vitamin $\mathrm{C}$ & $63.6(30.7)$ & $46.6(26.0)$ & 0.018 & $67.2(31.1)$ & $64.2(30.9)$ & 0.630 \\
\hline & fruits & $76.3(52.6)$ & $49.0(65.1)$ & 0.062 & $87.4(60.1)$ & $75.4(61.9)$ & 0.324 \\
\hline & vegetables & $92.9(37.7)$ & $77.4(32.8)$ & 0.053 & $84.9(31.1)$ & $91.0(39.0)$ & 0.410 \\
\hline $\begin{array}{l}\text { Past history or present illness } \\
\text { (Hypertension) }\end{array}$ & & $33.33 \%$ & $22.22 \%$ & 0.224 & $59.46 \%$ & $36.94 \%$ & 0.016 \\
\hline
\end{tabular}

者と未受診者との差は若年では有意ではないが，高年齢 区分になるほど大きく有意になった。また， 1 人当たり 医療費も 1998 年度の 40 歳代男性を除く全年齢区分で健 診受診者の方が低く，その差は高年齢区分になるほど大 きくなった。1 日当たり医療費は若年では健診受診者の 方が高いが, 高齢になると逆転し，70 から 80 歳代以降 は健診受診者の方が低くなった。1 件当たりの受診日数 は 1998 年度の 40 歳代男性を除き, 健診受診者の方が有 意に少なかった。受診率は 1998 年度の 40 歳代男性を除 く全年齢区分で健診受診者の方が低かった（Table 4, 5)。

1998 年度・1999 年度, 男性・女性, において, 1件当 たり及び 1 人当たり全医療費とも高年歯区分になるにつ れ高額になるが，健診受診者は健診未受診者に比べその 伸びが有意に少なかった（Fig. 1，2，3）。

すべての結果において 1998 年度と 1999 年度, 男性と 女性で同様の傾向があった。

\section{2. 生活習慣等に関する分析}

男性の健診受診者は未受診者に比べ以下の特徴があっ た。運動習慣のあるものの割合が有意に高く実際の歩数 （特に休日）も有意に多かった。また，自己の体力に関す る評価は「ふつう」とするもの，各がん検診受診をする ものの割合が有意に高く，体重コントロールに気をつけ ているものの割合が高い傾向があった。また不安スコア が有意に少なく，抑うつスコアも低い傾向があつた。食 事内容では野菜や果物を多く摂取する傾向があり，ビタ

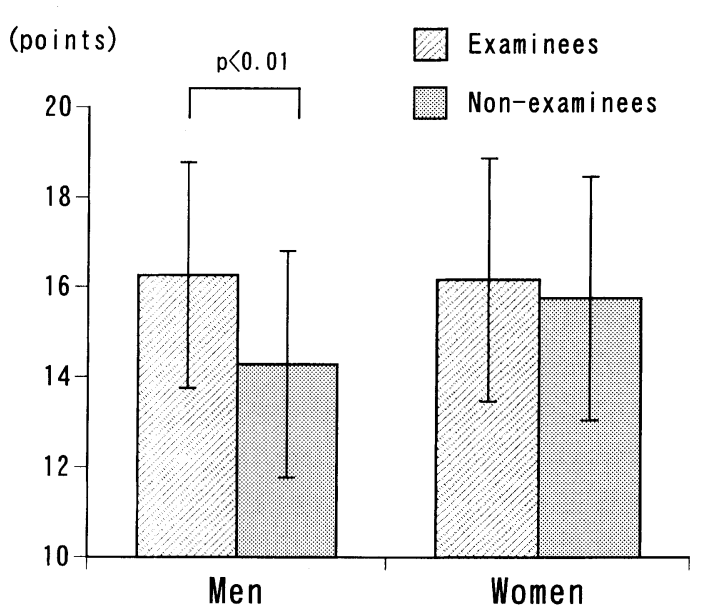

Fig. 4 Living Habits Score.

In men, the score is significantly higher among the basic health checkup examinees than the non-examinees.

ミン類やカルシウム, 食物緎維の摂取が有意に多かった。 睡眠, 喫煙, 食事に関する習慣, 歯科に関すること, 仕 事ストレス, 疲労, 既往歴・現病歴, 健康度の自己評価, 健康知識, 病休日数, 地域活動参加状況などに差は見ら れなかった。女性では健診受診者で高血圧の既往を有す るものの割合と他のがん検診を受けるものの割合が有意 に高いほかは健診受診者と末受診者で特に大きな差が見 られなかった（Table 6）。生活習慣指数は，男性では健 診受診者の方が有意に高得点であったが，女性では健診 
受診者と未受診者では差が見られなかった（Fig. 4)。ま た，男性と比べて有意に女性の点数が高かった。

\section{考察}

今回の結果で，健診受診者における高齢者の外来医療 費や入院医療費は未受診者に比へてて低かった。また，健診 受診の有無による医療費の差異は高齢者でより顕著で あった。このことより健診受診者では年齢に伴う医療費の 上昇が抑制されている可能性が示唆された。中西らは定期 健診の受診は高齢者の ADL 低下を遅らせ, disability のス コアを下げ,その効果は他の条件をコントロールしても独 立していたと報告している8)。また健診受診は高齢者の寿

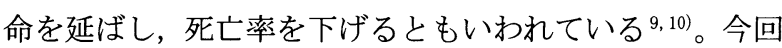
の調査の結果は, これらと同様の理由があるのかもしれ ない。また, 今回の結果で, 健診受診者は入院受診率が 低く外来受診率が高いこと，また健診受診者は外来での 1 件当たり医療費が低く, 入院においては, 1 件当たり医 療費, 1 人当たり医療費，高齢者の 1 日当たり医療費が 低く，入院日数が少ないことがわかった。これらの結果 は性別や年度により異なることはなく, 安定した傾向で あると思われる。この理由として，健診受診者は，健診 による早期発見によって, 慢性の疾患等での定期受診, あるいは軽微な疾患での外来受診は頻繁にするが入院に 至るような重篤な疾患になることは少なく，仮に入院し ても入院期間が短く費用も低く済むといら基本健康診查 の本来の目的である二次予防の効果が現れていると考え られる。そのため, 健診受診の有無による医療費の差異 は, 疾病や長期入院が増加寸る高齢者で顕著になったの かもしれない。

また今回の結果で, 男性の健診受診者は健診未受診者 に比べて生活習慣が良好で, 特に運動や健康的な食事, 体重の自己管理を心掛けていること，抑うつ・不安が少 なく精神的にも健康であることが明らかになった。これ

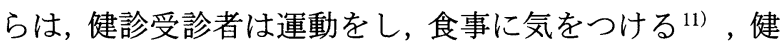
診受診者は運動をし，体重維持を心掛ける ${ }^{12)}$ ，健診受診 男性は死亡リスクが低い13) とした以前の報告とも一致 する。健診受診者の生活習慣が健康的である理由が，も ともと健康的な生活をする人々が健診を受診する傾向 があるためなのか，受診の結果，健康が保たれているの か, どちらであるかはわからない。前者であれば医療費 に対するバイアスになる可能性があるし，また，本来必 要な人に健診が行き届いていないという問題点がある ことになる。一方で，高齢者における健診受診の効果は 主にモラールの向上にあるという報告がある ${ }^{14,15)}$ 。ま た, 豊田市では基本健診の結果返却時には同時に健康指 導もなされている。それらを考慮に入れるならば，健診 受診によるモラール向上がよい生活習慣を生み, 結果と して医療受診を減らしたという可能性も考えられる。ま た，今回，女性は男性に比べ全体に生活習慣が良く，女 性では健診受診者と未受診者で生活習慣にあまり差が
見られないという結果であった。健診受診者群と健診未 受診者群での調查票回収率の比較において, 男性では有 意差が見られなかったが，女性では，受診者群の回収率 $97.4 \%$ に比べ, 未受診者群の回収率が $88.6 \%$ と有意に低 かった（p<0.01）ことから，女性の未受診者でより生活 習慣の悪い群のデータが得られなかったことも一因と なっている可能性がある。

今回の結果で, 若年者の外来 1 人当たり医療費と入院 1 日当たり医療費は健診受診者の方が高かった。若年者 では，健診受診者で外来受診率が高く，これが本来低受 診率である若年者の医療費に大きく影響したのかもしれ ない。今回の結果で健診受診者は他のいろいろな健診も また受診する傾向がある事がわかった。このことより， 健診受診者は積極的に医療機関も受診する傾向があると 予測できる。以前の研究でも健診受診者は病院受診も多

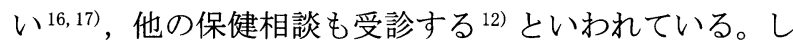
かし，1 日当たり入院医療費の高值の原因は不明である。 今回は医療費の総費用のみの分析であったが, 今後, 受 診科や疾患名等の医療内容の詳細な調査が必要であろ う。また, 今回の調查では若年者における対象者数が少 ないという難点もあった。今後，各年齢層にまたがった より多くの対象者を調べる必要がある。また，今回は老 人保健分と一般分をあわせて分析を行った。しかし，国 保一般対象者は健保対象者を除いた自営業等中心である など，年齢の差のみでなく，もともとの属性の差がある ため, 老人保健対象者と国保一般対象者を同様に比較す ることは困難であると考えられる。今後, 職域の健保対 象者も含めた総合的な調査をする必要がある。

医療の受診には医療の供給量や医療へのアクセス ${ }^{18-21)}$, 家庭状況 ${ }^{22)}$ など樣々な交絡因子が関連しており, 今回の 結果が本当に純粋に健診受診の効果であると断言するこ とはできない。以前の欧米の研究では予防プログラムは ほとんど医療支出を減らさない23) 75 歳以上の高齢者の ための健診の効果は疑わしい ${ }^{24,25)}$ としている。イギリス で行った RCTs では健診は physical problems や ADL の改 善はしないという結果であった ${ }^{15)}$ これれを明らかにす るためには, 現在まで未受診の者が受診をしたことに よって医療費がじうなるか，現在同等の医療費の者で今 後健診を受診した場合としなかった場合で将来の医療費 に差が見られるかなどの前向きの研究をする必要があ る。また, Hendriksen らは彼らの行った RCTsにおいて, 医学的社会的介入群で入院が減り, mortality が下がった のは介入により aids and modifications の配給が増したせ いであろうと述べている ${ }^{26)}$ 。他の保健サービスの提供が 多いと医療費が低く特に外来医療費を抑制する ${ }^{27)}$ 保健 施設費が高いと医療費が安い28) という報告からも健診 が医療受診を補っている ${ }^{4)}$ ために健診受診者の医療費が 低いことも考えられる。また, 疾病を予防して寿命を延 ばすことは最終的には社会全体としてのへルスケアコス 卜を引き上げる ${ }^{29)}$ という報告もある。また，医療機関を 受診しているために健診に行かなくなる ${ }^{30,31)}$ など, 健診 
実施時の医療機関受診の有無が基本健診受診に影響を与 える可能性がある。しかし今回は過去の医療受診のデー タが得られなかったためこの点については検討できな かった。また, 医療費や保健行動には, 収入 ${ }^{32}$, 保険本 人か家族かなど，個人の社会経済的状態の影響を受ける 可能性があるが, それも今回はデータが得られなかった。 健診受診が本当に総合的な社会全体のヘルスケアコスト を下げるかどうかの検討にはもっと広範囲で長期的な調 査が必要であろう。

今回の対象地域は中部圈の人口約 35 万人の都市部で ある。人口 10 万人以上の市に限定しても都市部の人口は 全国人口の約 6 割を占めており ${ }^{33)}$, 国民全体の医療費削 減という観点から見て都市部の研究は非常に重要である と考えられる。また従来調査されているような農村部に 比べ都市部は病院, 病床数や医師数が多い ${ }^{34)}$, 交通が発 達している等医療へのアクセスが良く，そのために医療 費が高い 19-22,35)。また, 都市部では医療を受ける機会だ けでなく, 人間ドックや企業の健診など他の健診を受け る機会も多く, 相対的に基本健診受診率が低くなる ${ }^{36,37) 。 ~}$ 我々の市民生活実態調査の結果でも基本健診以外の健診 を受診した人が健診受診者中約 $70 \%$ 存在した。逆に医療 施設の乏しい地域では基本健診以外の健診機会がない， 医療受診の代替として健診を利用している等，都市部と は基本健康診査の位置付けが異なる可能性がある。以上 の理由から, 地域毎の比較をした今までの研究では都市 と農村の差異を見ていただけかもしれない，あるいは都 市部での基本健診は農村部に比べ意義が少ないかもしれ ないという可能性があったが, 今回の分析で 同一都市内 でも先行研究と同様に基本健診受診者の医療費が低いと いう結果が得られたことは意義がある。

いずれにしても, 今回の結果より, 基本健診受診者群 は医療費という観点からみて望ましい集団であること がわかった。しかし，今回のような医療や他の健診にも アクセスの良い地域で基本健診受診者の医療費が低い ことは, 基本健診受診の効果が単純に従来言われている ような早期発見早期治療の二次予防の結果だけではな い可能性を示唆させる。機序は不明であるが，受診者に おいて, 生活習慣改善等による何らかの一次予防効果が みられるのではないだろうか。McEwan らが，政府は高 齢者の定期検診の目的をはっきりとすべきだと言って いるように ${ }^{15)}$ ，ただ基本健診受診率の向上のみを唱える のではなく, 今後は健診受診の効果の本質をより明らか にして行く必要がある。そして，それに基づいた健診受 診勧奨のターゲットや実施方法・内容の再検討，健康教 育等他の代替事業充実の検討などにより，より費用対効 果の高い保健事業の展開が可能となるであろう。

\section{謝辞}

稿を終えるにあたり，ご指導を賜りました愛知医科大 学医学部教授小林章雄先生, 名古屋女子大学助教授酒井
映子先生，また調査にご協力いただいた子安春樹豊田市 保健所長ならびに豊田市福祉保健部の皆様に心より感謝 いたします。

\section{文献}

1）財団法人厚生統計協会. 国民衛生の動向. 東京 : 財団 法人厚生統計協会 $2000 ； 114,432 ， 483$.

2) Nakanishi N, Tatara K, Fujiwara H, Do preventive health services reduce eventual demand for medical care? Soc.Sci.Med. 1996; 43 (6) : 999-1005.

3) Tatara K, Shinsho F, Suzuki M, Takatorige T, Nakanishi N, Kuroda K. Relation between use of health check ups starting in middle age and demand for inpatient care by elderly people in Japan. BMJ 1991；302: 615-618.

4) Matsuda S. Regulatory effects of health examination programs on medical expenditures for the elderly in Japan. Soc.Sci.Med. 1996; 42 (5) : 661-670.

5）川口 毅, 三浦宜彦，星山佳治，星野祐美，関山昌人， 岩崎 榮. 老人保健事業と医療費との関連に関する研 究. 日本公衛誌 $1995 ； 42(9) ： 761-768$.

6) 新庄文明, 福田英輝, 村上茂樹, 高鳥毛敏雄, 中西範 幸, 多田羅浩三. 基本健康診査受診率と国民健康保険 診療費の関連に関する研究 受診率 $50 \%$ 以上の市にお ける実態. 日本公衛誌 $2001 ; 48(4) ： 314-323$.

7）澤田賢三，金本恵美子．滋賀県 $\mathrm{A}$ 町における住民健診 受診の有無と老人医療費の関係について. Bull. Natl. Inst. Public Health 1997; 46 (1) : 29-35.

8) Nakanishi N, Tatara K, Takashima Y, Fujiwara H, Takamori Y, Takabayashi H, Scott R. The association of health management with the health of elderly people. Age and Aging 1995; $24: 334-340$.

9) Nakanishi N, Tatara K, Takatorige T, Murakami S, Shinsho F. Effects of preventive health services on survival of the elderly living in a community in Osaka, Japan. J Epidemiol Community Health 1997; 51: 199-204.

10) Norman J Vetter, Dee A Jones, Christina R Victor. Effect of health visitors working with elderly patients in general practice: a randomised controlled trial. BMJ 1984; 288: 369372 .

11）武村真治，橋本廸生，郡司篤晃．受療行動と予防的保 健行動との関連. 日本公衛誌 $1997 ； 44(2) ： 102-112$.

12）福永一郎, 實成文彦, 武田則昭, 浅川冨美雪, 丸山保 夫. 無職高齢者の保健行動に関する研究一健康診查受 診行動と保健行動との関連について一．日衛誌 1997; $52(2): 490-503$.

13）訔嵉俊郎, 田島和雄, 吉田 京, 富永祐民. 健康づく り努力度別にみた死亡リスクの検討 愛知県農山間部 一般住民におけるコホート研究より．日本公衛誌 1999; $46(10): 904-914$

14) A J Tulloch, V Moore. A randomized controlled trial of geriatric screening and surveillance in general practice. Journal of the Royal College of General Practitioners 1979; 29: 733-742

15) Robert T McEwan, Nigel Davison, Donald P Forster, Pauline Pearson, Ellie Stirling. Screening elderly people in primary 
care: a randomized controlled trial. British Journal of General Practice 1990；40：94-97.

16）小笹晃太郎. 成人健康診査受診群の特徵 第 1 報 受診 経験の有無による比較研究. 日衛誌 1988；43(5)：9951003.

17）小笹晃太郎. 成人健康診査受診群の特徵 第 2 報 受診 行動の変化にもとづいた比較研究. 日衛誌 1988；43(5)： 1004-1012.

18）太田圭洋，山内一信. 医療従事者数及びその雇用費用 が医療費に及ぼす影響に関する分析．病院管理 1997 ; $34(4): 357-366$.

19）山下真宏. 老人医療費の 3 要素に影響を及ぼす要因に関 する研究. 日本公衛誌 $1998 ； 45(3) ： 225-239$.

20）今井博久, 一色学, 荒田吉彦, 杉澤孝久, 竹内徳男, 斎 藤和雄. 二次医療圈における老人医療費と保健活動, 医 療供給, 福祉事業との関連性. 病院管理 1998; 35(2): $25-33$.

21）張拓紅, 谷原真一, 柳川 洋. 二次医療圈単位で観察 した国保老人保健医療給付対象者医療費の地域格差に 関する研究. 日本公衛誌 $1998 ; 45(6) ： 526-535$.

22）畧博. 福岡県における老人医療費とその地域格差 の規定要因に関する研究. 日本公衛誌 1996；43(1)：2836.

23) Louise B Russell. The economics of prevention. Health Policy $1984 ; 4: 85-100$.

24) M.A Roworth. Screenimg in the elderly. Public Health 1989; 103: 377-383.

25) Andrew Harris. Health checks for people over 75-the doubts persist. BMJ 1992; 305: 599-600.

26) Hendriksen, E Lund, E Strømgård. Consequences of assessment and intervention among elderly people: a three year randomised controlled trial. BMJ 1984; 289: 15221524.
27）中西範幸，多田羅浩三．大阪府下 44 市町村における入 院，および入院外医療需要と保健サービスの関連につ いての検討. 病院管理 $1997 ; 34(3): 55-62$.

28）中瀬克己. 保健事業と医療費との関係一健康保険組合 の保健施設事業の評価一. 岡山医学会雑誌 1988；589597.

29) Luc Bonneux, Jan J Barendregt, Wilma J Nusselder, Paul J Van der Maas. Preventing fatal diseases increases healthcare costs: cause elimination life table approach. BMJ 1998; 316: 26-29.

30）溝上哲也，高野由起子，吉村健清. 都市部住民の健康 診査受診行動. 日本公衛誌 $1992 ； 39(5) ： 269-277$.

31）藤田真理子，池田澄子，室 潤子. 基本健康診査未受 診者の健康管理状況一 $\mathrm{I}$ 市 U 地区の基本健康診査対象 者の調查から．厚生の指標 1996；43(6)：3-10.

32）石井敏弘, 清水弘之, 西村周三, 梅村貞子. 入院・入 院外別老人医療費と社会・経済, 医療供給, 福祉 - 保 健事業との関連性. 日本公衛誌 $1993 ； 40$ (3)：159-170.

33）市町村自治研究会. 住民基本台帳人口要覧（平成 12 年 版). 東京：財団法人国土地理協会 2000；565-566.

34) Kobayashi Y, Takaki H. Geographic distribution of physicians in Japan. The Lancet 1992；340：1391-1393.

35）谷原真一, 張拓紅, 尾島俊之, 中村好一, 柳川 洋, 小 林雅與. 二次医療圈毎にみた医療供給と受療行動の関 連および地域格差. 日本公衛誌 1997；44 (9)：688-693.

36）福田英輝, 山田敦弘, 井田修, 多田羅浩三, 水野 肇, 山口 昇, 田中一哉. 基本健康診査受診率と老人 保健給付分による診療費ならびに診療実日数との関 連. 日本公衛誌 1998；45(9)：905-914.

37）武村真治，府川哲夫，中原俊隆，近藤健文．全国の市 における老人保健事業の費用とその関連要因. 日本公 衛誌 1997；44(5)：353-363. 